\title{
Anti-CD20 therapy for heart attack
}

\section{By Michael J. Haas, Senior Writer}

A multinational team has taken a new approach to treating heart attacks: depleting the host of $\mathrm{B}$ cells that recruit monocytes to the infarct site, where they further inflame and damage tissue. ${ }^{1}$ The mouse findings hand a new indication to companies that market or are developing antibodies against CD20 on B cells to treat cancer and autoimmune diseases.

The team is planning a Phase IIa trial of the anti-CD20 mAb Rituxan/MabThera rituximab in patients with myocardial infarction (MI) at several hospitals in Cambridge, U.K., and Paris and is discussing partnering options for the trial with one or more of the companies that market the mAb.

Meanwhile, at least one biotech that has an anti-CD20 antibody is discussing the new findings with its pharma partner.

The ischemic damage caused by MI reduces cardiac function and can lead to death or recurrence of MI. Multiple studies have shown that MI activates components of the innate immune system that

"Our findings suggest that a single dose of an anti-CD20 antibody delivered shortly after MI could reduce the risk of death or recurrence." - Ziad Mallat, Institut National de la Santé et de la Recherche Médicale

Next, the team treated the mouse models at one hour and one day postinfarction with a murine anti- $\mathrm{Cd} 20 \mathrm{mAb}$. The treatment decreased circulating levels of $\mathrm{Ccl} 7$ and consequent monocyte recruitment to the infarct site compared with vehicle, thereby reducing infarct size and increasing cardiac function.

Also in the mouse models of MI, the team found that deficiency in BLyS (Baff) receptor-which is necessary for maintaining mature $\mathrm{B}$ cells-decreased levels of circulating $\mathrm{Ccl} 7$ and increased cardiac function compared with what was seen in wild-type controls. Although the BLyS receptor deficiency did not affect infarct size, this did not necessarily mean BLyS receptor inhibition would be less effective than CD20 inhibition at treating MI. "The BLyS receptor was absent throughout development in the mice, which would not be the case in a short-term therapeutic strategy in adults," Mallat told SciBX.

Lastly, the team showed that levels of CCL7 and BLyS ligand in the serum of patients with MI were associated with an increased risk of death and recurrent MI.

"Our findings suggest that a single dose of an anti-CD20 antibody delivered shortly after MI could reduce the risk of death or recurrence," Mallat told SciBX.

The team included researchers from the University Paris Descartes, Paris Diderot University, the Pierre and Marie Curie University, Lariboisière Hospital, Saint Antoine Hospital, Georges Pompidou European Hospital, the Medical University of Vienna, the Austrian Academy of Sciences, the Gladstone Institute of Cardiovascular Disease and Duke University Medical Center.

Data were reported in Nature Medicine.

contribute to cardiac inflammation and damage, including complement factors, neutrophils and monocytes. ${ }^{2-7}$

B cells, however, have been absent from that list because the cells' role in innate immune responses to post-ischemic and other types of acute injury is poorly understood.

Ziad Mallat and his team have now studied whether B cells play a role in cardiac inflammation and damage after MI and whether the cells or their downstream effectors could be targeted to treat the indication.

Mallat is professor of cardiovascular medicine at Addenbrooke's Hospital and team leader of the immunity, inflammation and atherosclerosis group at the Institut National de la Santé et de la Recherche Médicale (INSERM).

The team examined cardiac tissue from mouse models of MI and found greater infiltration of mature B cells at the infarct site than that seen in cardiac tissue from healthy controls. The number of infiltrating B cells peaked at day five postinfarction and waned thereafter.

Circulating and cardiac levels of chemokine CC motif ligand 7 (Ccl7; Mcp3; Scya6) - a protein that can trigger mobilization of monocytes from bone marrow to injured tissue-were higher in the MI models than in healthy controls. Additional experiments in the models showed that after infarction, B cells in the heart and circulation secreted Ccl7, triggering the recruitment of proinflammatory monocytes to the infarction site.
Biogen Idec Inc., Roche and its Genentech Inc. unit market Rituxan, a chimeric mAb against CD20, to treat rheumatoid arthritis (RA), multiple sclerosis (MS), inflammatory disease, lymphoma, non-Hodgkin's lymphoma (NHL) and chronic lymphocytic leukemia (CLL). The partners also have the $\mathrm{mAb}$ in Phase III testing to treat mantle cell lymphoma (MCL).

\section{Repurposeful thinking}

Multiple companies market or are developing antibodies against CD20 for cancer, autoimmune diseases and inflammatory indications that could be repurposed to treat MI (see Table 1, “CD20: new angle of attack”).

Although the team's findings in mouse models did not allow a direct comparison of therapeutic strategies, Mallat said that anti-CD20 antibodies would probably be more effective than inhibitors of BLyS-BLyS receptor signaling because the former deplete B cells rapidly after a single dose, whereas the latter take longer to deplete B cells and alter their functions.

Additionally, the BLyS receptor may be expressed on cells other than $B$ cells and thus could lead to side effects, he said.

"The role of B cells in ischemic injury has long been neglected," said Paul Parren, SVP and scientific director at Genmab A/S. "This new study certainly makes a strong case for investigating the impact of B cell depletion with anti-CD20 therapy after acute myocardial infarction." 
Table 1. CD20: new angle of attack. A study by a multinational team suggests that depleting B cells with anti-CD20 therapy shortly after myocardial infarction (MI) could reduce infarct size and improve cardiac function, thereby reducing the risk of death or recurrent MI. The findings offer a repurposing opportunity to companies that market or are developing anti-CD20 antibodies to treat cancer, autoimmune diseases and inflammatory indications. Additionally, at least eight other companies market or are developing biosimilars of the anti-CD20 antibody rituximab to treat cancer and autoimmune indications.

Source: BCIQ: BioCentury Online Intelligence

\begin{tabular}{|c|c|c|c|}
\hline Company & Anti-CD20 antibody ${ }^{A}$ & Antibody type & Status \\
\hline $\begin{array}{l}\text { Biogen Idec Inc. (NASDAQ:BIIB)/Roche } \\
\text { (SIX:ROG; OTCQX:RHHBY)/Genentech } \\
\text { Inc. }\end{array}$ & $\begin{array}{l}\text { Rituxan/MabThera } \\
\text { rituximab }\end{array}$ & Chimeric $\mathrm{mAb}$ & $\begin{array}{l}\text { Marketed for chronic lymphocytic leukemia (CLL), } \\
\text { lymphoma, non-Hodgkin's lymphoma (NHL), inflammatory } \\
\text { disease, multiple sclerosis (MS) and rheumatoid arthritis } \\
\text { (RA); Phase III to treat mantle cell lymphoma (MCL) }\end{array}$ \\
\hline $\begin{array}{l}\text { Genmab A/S (CSE:GEN;OTCBB:GMXAY)/ } \\
\text { GlaxoSmithKline plc (LSE:GSK; NYSE:GSK) }\end{array}$ & Arzerra ofatumumab & Human $\mathrm{mAb}$ & $\begin{array}{l}\text { Marketed for CLL; Phase III for B cell lymphoma, NHL, } \\
\text { pemphigus vulgaris (PV) and RA; Phase II for MS }\end{array}$ \\
\hline $\begin{array}{l}\text { Roche/Genentech/Chugai Pharmaceutical } \\
\text { Co. Ltd. (Tokyo:4519)/Nippon Shinyaku } \\
\text { Co. Ltd. (Tokyo:4516; Osaka:4516) }\end{array}$ & $\begin{array}{l}\text { Obinutuzumab (GA101; } \\
\text { RG7159; RO5072759) }\end{array}$ & $\begin{array}{l}\text { Glycoengineered, humanized } \\
\mathrm{mAb}\end{array}$ & $\begin{array}{l}\text { In registration for CLL; Phase III for B cell lymphoma } \\
\text { and NHL }\end{array}$ \\
\hline $\begin{array}{l}\text { Roche/Chugai Pharmaceutical/ } \\
\text { Genentech/Halozyme Therapeutics Inc. } \\
\text { (NASDAQ:HALO) }\end{array}$ & Subcutaneous rituximab & Chimeric $\mathrm{mAb}$ & In registration for $\mathrm{NHL}$ \\
\hline Biogen Idec/Roche/Genentech & $\begin{array}{l}\text { Ocrelizumab (R1594; } \\
\text { RG1594) }\end{array}$ & Humanized $\mathrm{mAb}$ & Phase III for MS \\
\hline $\begin{array}{l}\text { Immunomedics Inc. } \\
\text { (NASDAQ:IMMU)/Takeda } \\
\text { Pharmaceutical Co. Ltd. (Tokyo:4502) } \\
\end{array}$ & $\begin{array}{l}\text { Veltuzumab (hA20; } \\
\text { IMMU-106) }\end{array}$ & Humanized $\mathrm{mAb}$ & $\begin{array}{l}\text { Phase II for lupus; Phase I/II for CLL, NHL, hematological } \\
\text { malignancies and idiopathic thrombocytopenic purpura } \\
\text { (ITP); preclinical for pancreatic cancer }\end{array}$ \\
\hline $\begin{array}{l}\text { LFB S.A./Ildong Pharmaceutical Co. } \\
\text { Ltd. (KSE:000230)/TG Therapeutics Inc. }\end{array}$ & $\begin{array}{l}\text { Ublituximab (LFB-R603; } \\
\text { TG-1101; TGTX-1101) }\end{array}$ & Chimeric $\mathrm{mAb}$ & Phase I/II for B cell lymphoma, CLL and NHL \\
\hline
\end{tabular}

Ltd. (KSE:000230)/TG Therapeutics Inc. (NASDAQ:TGTX)

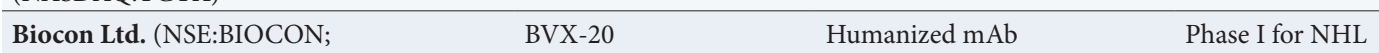

BSE:BIOCON)/Vaccinex Inc.

${ }^{A}$ Does not include anti-CD20 antibodies that are radiolabeled, bispecific or multivalent.

Genmab is focused on cancer, but Parren said that the possibility of repurposing its Arzerra ofatumumab "is certainly something we would want to discuss" with partner GlaxoSmithKline plc.

Genmab and GSK market Arzerra, a human mAb against CD20, to treat CLL. Arzerra has breakthrough therapy designation for first-line treatment of CLL in the U.S.

The partners also have the mAb in Phase III testing to treat B cell lymphoma, NHL, RA and pemphigus vulgaris (PV) and in Phase II testing to treat MS

Before deciding whether anti-CD20 therapy is feasible in patients with MI, "we would like to see investigations on timing and dosing in the mouse model," Parren said. "In cardiac ischemic injury, the timing of treatment is of the essence. So it would be important to find out how much time there is-after cardiac injury - for the anti-CD20 therapy to be helpful."

Additionally, he said, "titrating the dose of the anti-CD20 therapy in mice should indicate the magnitude of $\mathrm{B}$ cell depletion required to achieve the therapeutic effect, and repeat dosing should indicate whether prolonged therapy improves the results."

Mallat said that his team already has run the type of timing and dosing studies suggested by Parren but declined to disclose details. He noted that the team also has unpublished data showing that the window of time during which monocyte recruitment to the infarct site can be blocked by depleting $\mathrm{B}$ cells is similar in the mouse models and in patients with MI.

INSERM and the University of Cambridge have filed for a patent covering the findings, and the IP is available for licensing, Mallat said.

He declined to disclose with which of the companies that market
Rituxan-Biogen Idec, Roche or Genentech-his team is discussing a partnering deal for the Phase IIa trial.

Haas, M.J. SciBX 6(37); doi:10.1038/scibx.2013.1015

Published online Sept. 29, 2013

\section{REFERENCES}

1. Zouggari, Y. et al. Nat. Med.; published online Sept. 15, 2013; doi:10.1038/nm.3284

Contact: Ziad Mallat, Institut National de la Santé et de la Recherche Médicale (INSERM), Paris, France e-mail: zm255@medschl.cam.ac.uk

2. Zhang, M. et al. J. Exp. Med. 203, 141-152 (2006)

3. Vinten-Johansen, J. Cardiovasc. Res. 61, 481-497 (2004)

4. Pepys, M.B. et al. Nature 440, 1217-1221 (2006)

5. Nahrendorf, M. et al. J. Exp. Med. 204, 3037-3047 (2007)

6. Salio, M. et al. Circulation 117, 1055-1064 (2008)

7. Leuschner, F. et al. J. Exp. Med. 209, 123-137 (2012)

\section{COMPANIES AND INSTITUTIONS MENTIONED}

Addenbrooke's Hospital, Cambridge, U.K. Austrian Academy of Sciences, Vienna, Austria Biogen Idec Inc. (NASDAQ:BIIB), Weston, Mass. Duke University Medical Center, Durham, N.C. Institut National de la Santé et de la Recherche Médicale, Paris, France

Genentech Inc., South San Francisco, Calif.

Genmab A/S (CSE:GEN; OTCBB:GMXAY), Copenhagen, Denmark Georges Pompidou European Hospital, Paris, France

Gladstone Institute of Cardiovascular Disease, San Francisco, Calif. GlaxoSmithKline plc (LSE:GSK; NYSE:GSK), London, U.K.

Lariboisière Hospital, Paris, France

Medical University of Vienna, Vienna, Austria 


\section{ANALYSIS}

Paris Diderot University, Paris, France

Pierre and Marie Curie University, Paris, France

Roche (SIX:ROG; OTCQX:RHHBY), Basel, Switzerland
Saint Antoine Hospital, Paris, France

University of Cambridge, Cambridge, U.K.

University Paris Descartes, Paris, France 